\title{
The Impacts of Credit Growth in China on Economic Growth of China
}

\author{
Wen Yang \\ College of Business Administration, University of Nebraska Lincoln, Lincoln, Nebraska 68588, USA \\ yangwen927@gmail.com
}

Keywords: Credit growth, Economic growth, Attitude.

\begin{abstract}
Does it have some connection between credit growth and economic growth in China? This paper studied the impacts of credit growth in China on economic growth of China. Credit growth and economic growth have a strong relationship to stimulate the economy. In this paper, there are some positive attitude showing to reduce the corporate credit to make the growth rate of China stable. Some negative attitude show that the excessive expansion of the credit will negatively affect the economy of China. Therefore, using mixed strategies and austerity measures to attain rapidly economic growth and regard credit as a huge problem.
\end{abstract}

\section{Introduction}

Credit is the amount of money that borrowers receive by entering into contractual agreements that define terms and conditions under which the sum of money will be returned (with interest) to the lender after a predetermined time period. Given that commercial banks are the main entities that provide credit, it can be said that they play a major role in the growth of credit. In effect, banks not only give loans but in the process they increase the supply of money in the economy, thus leading to the growth of credit and to enhanced potential for the economy's growth. Credit growth and economic growth are connected because increase in credit implies availability of greater financial resources that can be used to invest in production processes, which result in enhanced production, higher income levels, increased demand and overall stimulation of the economy in attaining higher economic growth.

According to Ross Levine and Sara Zervos, stock markets and banks promote long-run economic growth and financial markets provide important services for credit growth [1]. Theoretically, the process of money creation is carried out by banks that involve in the giving of credit to individuals and business entities. When individuals and businesses deposit money in the bank, their money remains intact, but the bank uses it to lend it as credit to others on interest for meeting their financial needs. Therefore, banks involve in credit growth and in the process increase the total money available in the economy [2]. Economic growth in any year is the increase in the country's Gross National Product (GNP) for the given year [3]. According to Stefan Avdjiev, Robert McCauley and Patrick McGuire, the contribution to overall credit growth has been modest outside the more dollarized economies of Asia [4]. The main cause of economic growth in any country is the extent to which its capital stock increases through investments, which are primarily funded through credit provided by banks. Therefore, there is a strong link between credit growth and economic growth; meaning that availability of credit is a major requirement for economic growth. According to Kpodar and Kodzo, a positive relationship exists between credit growth and economic growth [5]. In providing credit to businesses, banks help in allocating capital and reducing transaction costs in the short term, which stimulates the economy and thus leads to economic growth. However, economic growth tends to be negative if the banks in a country involve in excessive credit expansion because government policies directed at increasing money supply. Excessive increase in money supply leads to inflationary patterns and to decline in economic growth in the long term. Recently in China there has been a big surge in credit usage. Many wonder what effect this may 
have on the economy going forward. In this paper, it will show that there are some of possible outcomes and what will come with China's credit growth.

\section{Attitude of credit growth in China}

\subsection{Positive Attitude}

According to IMF company credit advancement in China has was enormous there was a need to reduce it. The credit affluent is associated with a massive increase in the investment following the worldwide financial crisis. Efficiency in investments has dropped, and there is steady deterioration of corporate financial performance which is affecting the quality of assets in financial institutions. The issues of corporate credit in China requires primary addressing using a comprehensive strategy. The main strategies include restructuring of the corporate credit and decreasing the business credit. This proactive technique is expected to have a short-term decline in the economic growth, but there will be a long-term gain [6].

Bloomberg reported that China would try to lower the growth of the economy and monetary expansion because the policy makers are attempting to curb the excessive credit growth and thus reduce financial risk. The growth of domestic product is expected to be 6.5 more than last years'. According to a survey done by analysts M2 money supply will be at $11.5 \%$ compared to 2016 which was $13 \%$ and the leaders are expected to allow the economic growth to hum at around $6.5 \%$ to make China moderately prosperous by the year 2020. However, the consumer inflation will not be changed and is expected to remain at 3\% this year [7].

The IMF upgraded the China economy growth forecast to 6.5 in January. This was an increase of 0.3 compared with the estimation from October of last year. The second largest economy had a rocky start this year. The consumption is sustaining, factories have recovered from a 4-year deflation streak, and the total growth is anticipated to meet the target of the government despite the decline. Economists are expecting another year of compact growth ahead of a reshuffle of the leadership of the communist party later in the year. Much of the country's rebound is associated with the surge of cheap credit unleashed by the government-run bank at the current administration request. The IMF said that the growth rate of China is more stable than expectations due to the continued policy stimulus, however it advised the country to reduce the corporate credit [6].

\subsection{Negative Attitude}

According to Evans -Pritchard, an economist based in Singapore, there is expected to be a slow decline in huge credit growth which began last summer to continue in the next months. The expected outcome is slowing of the economy which is to start sooner than previously anticipated. Orlik, an economist at Bloomberg, said that it is hard for the Chinese economy and the growth of the GDP to be maintained without the expansion of the credit. Although the government is insisting on the deleveraging, the number is not matching what they bring to the market and hence the risk and worry concerning the economy of China which is expected to continue declining [7].

New rule will weigh on the creation of credit. Starting this year, the people's Bank of China included a framework for assessing the expansion of credit; this indicates that the banks have to restrain the credit growth to comply with these regulations and hence lower the funding in the commerce system. This move will complicate the financial status of small companies and this will negatively affect the influence the economy of the country, manufacturing and the extensive economy may experience a drag from the second quarter of the year [7].

China's economy is slowing down, and the worry is how bad. In an article published in the New York Times in January China announced that the growth of the economy of $6.7 \%$. Based on the historical standard the growth of the economy has slowed down, and the economy was at its weakness growth pace in the last twenty-five years. Enodo Economics chief economist, Choyleva said that that the China economy has reached the end of the road when the investment-led model is put into consideration. The primary concern to the world is expected because China has been an economic engine for many years [8]. 
On the same note, in his annual speech the Chinese Prime Minister Li Keqiang, said that the 2015 growth was expected to be $7 \%$ which was lower by $0.5 \%$ compared to the previous years. It aligned with the slow growth with the reform suggested by the international monetary fund to avoid hard landing of the China economy through the reduction of corporate credit. This declaration by the premier is another indication that the cut off credit will slow the growth of the economy [9].

According to The Diplomat the Chinese economy is projected to have a very slow 2017. This is caused by a couple of factors including new financial policy and a recent slump in the Yuan. The biggest early sign of a potential slowdown is signified by the fact that "there are already signs that the property market is starting to cool” [10]. If this trend continues then the Chinese economy will continue to slow with their credit already peaking and expected to rise to 264\% of GDP [10].

\section{Conclusion}

Various researchers and economist have considered that reduction in credit will have a negative effect in the slowing of the economic in an attempt to avoid financial risk, manufacturing and the large economy will experience a drag due to lack of corporate credit. Some of those researchers and economist have positive attitude to show the impact of credit growth and some of them have negative. In order to attain faster rate of economic growth, China will have to make use of mixed strategies involving reduction of debt by restructuring its credit position and adopting austerity measures in terms of reducing borrowings and over-capacities. Even though those researchers and economist had proved their statement about the impact of credit growth, it does not show that the result will be the same as they proved. With the Chinese economy growing rapidly and having aspirations of becoming one of the largest markets in the world this credit issue is something that needs to be taken care of in the immediate future and the dangers of credit boom seem be a huge credit problem.

\section{References}

[1] Ross Levine and Sara Zervos: Stock Markets, Banks, and Economic Growth, The American Economic Review, 1998

[2] Werner, R. A. (2012). The Quantity Theory of Credit. Centre for Banking, Finance \& Sustainable Development. Retrieved from

https://www.postkeynesian.net/downloads/Werner/RW301012PPT.pdf

[3] Business Dictionary. (2017). Economic Growth. Retrieved from

http://www.businessdictionary.com/definition/economic-growth.html

[4] Stefan Avdjiev, Robert McCauley and Patrick McGuire: Rapid credit growth and international credit: Challenges for Asia, 2012

[5] Kpodar, K., and Gbenyo, K. (2010). Short- Versus Long-Term Credit and Economic Performance: Evidence from the WAEMU. IMF Working Paper WP/10/115.

[6] Maliszewski, W., Arslanalp, S., Caparusso, J., Garrido, J., Guo, S., Kang, J. S., ... Zhang, L. (2016). WP/16/203 resolving china’s corporate debt problem.

[7] Bloomberg. (2017). Retrieved February 28, 2017, from https://www.bloomberg.com/news/articles/2017-02-14/china-credit-surges-as-tightening-fails-to-tap

[8] GOUGH, N. (2016). As China’s Economy Slows, a Look at What Could Happen.

[9] Amighini, A. (2015). China’s Economic Growth. Heading to a "New Normal”.

[10] Fensom, Anthony. "China's GDP Growth: Slow and Slower?" The Diplomat. The Diplomat, 21 Jan. 2017. Web. 05 Mar. 2017. 